

\title{
Sukuk Linked Waqf Perspective Abu Zahra's Maqashid Sharia Model as Financial Investment Product
}

\author{
Ahmad Syaichoni ${ }^{1}$, Suminto ${ }^{2}$ \\ Islamic State University Sayyid Ali Rahmatullah ${ }^{1,2}$ \\ syaichoniahmad@gmail.com ${ }^{1}$, kangminto990@gamil.com ${ }^{2}$
}

\begin{abstract}
Indonesia is a country where the majority of the population is Muslim. One of the potentials that Indonesia has with its Muslim community is the waqf order. This great potential of waqf certainly provides a positive side for the state in the context of the welfare of its people. To improve people's welfare through the potential of waqf, the government through Otoritas Jasa Keuangan $(\mathrm{OJK})$ makes a sharia investment instrument that is linked to waqf, namely the Sukuk Linked Waqf product. This product is a combination of Sukuk and waqf. The emergence of this product is expected to be able to achieve the great potential of waqf and expand the market share of Islamic finance indirectly, the Sukuk Linked Waqf product is a product that is expected to increase sharia financial inclusion. The method used is a literature review of maqashid sharia and Sukuk. This study used critic analysis and content analysis to investigate the theory of maqashid sharia and Sukuk. The results showed that Sukuk Linked Waqf based on Abu Zahra's maqashid sharia model is a financial investment product that aims to bring benefits. The benefits, in this case, are in the form of welfare for humans in terms of economic improvement. Whit the emergence of this product, the road to the welfare of the people becomes more real.
\end{abstract}

Keywords: Sukuk Linked Waqf, Maqashid Sharia, Financial Investment.

\section{INTRODUCTION}

In human life, Islam teaches balance. Allah commands people to worship him and to do good to others. The interaction between people in response to their needs is regulated by Islam. But not all people can properly fulfill their needs. A gap between the rich and the poor must exist in social life. Socio-economic inequality is created by this. Indonesia, a country with plenty of natural resources, but with wealth distribution problems. The economic power of resources might provide their people with welfare. Statistical data from Badan Pusat identified that by September 2020, the percentage of poor people was 10,19\%; by March 2020, it evolved by 0,41 percentage points, and by September 2019, 0,97 percentage points. There were 27.55 million poor people in September 2020. (www.bps.go.id)

Through waqf command, Allah proposes a solution to economic and social human inequality. Waqf is a tool to enhance another well of individual citizens. With the concept waqf, not only do a few people possess human wealth, but the general populace can enjoy it. Since the arrival of Islam in Indonesia, Muslims have known and practiced Waqf, which is also incorrectly 
seen as a supporter of religious development and Islamic society (Ilmiah, 2019). Indonesia is a country where the majority of the population is Muslim. One of the potentials that Indonesia has with its Muslim community is the waqf order. This great potential of waqf certainly provides a positive side for the state in the context of the welfare of its people.

Waqf has two dimensions, a dimension of worship and an economic aspect. Waqf as an economic dimension that appears to give social welfare is developed in this modern era. Waqf is one of the socio-economic components of Islam that is taught. Indonesia, although the world's largest Muslim country, yet lags behind other Muslim countries in terms of waqf asset management, such as Egypt, Algeria, Saudi Arabia, Kuwait, and Turkey. In Indonesia, the implementation of waqf has been unsuccessful, particularly in terms of waqf asset management. Because the usage of assets is limited to anything physical, such as land, tombs, or durable items, management is still categorized as static (Fad, 2021).

Waqf, long known to the Indonesians, was unable to improve the economic conditions welfare of the community even more than feasible. Waqf assets cannot and tend to stagnate. The property, nevertheless, is not used for the community's economic development. Waqf has played a vital economic and financial role in history. Waqf is used to fund mosques, schools, study and research, hospitals, social services, and defense in Islam. Sukuk Linked Waqf can increase the productivity of Waqf in Indonesia. Many studies on asset optimization waqf are being conducted by the Ministry of Finance, Otoritas Jasa Keuangan, and Badan Wakaf Indonesia. People currently believe that a waqf asset is simply property on which a mosque or social organization can be erected. While this land waqf can be optimized using Sukuk Linked Waqf and as underlying assets employing the land waqf (Ilmiah, 2019).

Waqf development, which includes Sukuk as a funding mechanism, is now widely used in several nations, including Saudi Arabia, Singapore, and Malaysia (Fasha et al., 2018). Indonesia also attempts to create waqf by the mechanism of Islamic financial instruments. By increasing the market share of Islamic financial institutions, the government encourages efforts to enforce the Sharia economy. Waqf is a tool for the development of the Indonesian sharia economy. So is Waqf applied as a product through Islamic banks but also by the issuance of Sukuk Linked Waqf on the Islamic capital market.

Waqf, on the other side, is an instrument of Islamic altruism that grows under human ideals. If properly administered, waqf will become a key factor in addressing community socioeconomic issues such as poverty, health insurance, education, and unemployment. The government can use cash waqf assets to fund infrastructure projects that benefit the entire community (Fad, 2021). Waqf consequently becomes an effective component in the wellbeing of 
the people. Waqf's development in multiple ways ability to preserve in all sectors, even if they are economic, social, educational, or even religious.

Waqf and Sukuk have become two of the most popular Islamic financial tools. Today, each of them has evolved into the Sukuk-waqf, a new instrument (Musari, 2019). Both studies are interesting because of the different characteristics of Sukuk and waqf. However, the two instruments are combined to optimize people's welfare. To prevent a frozen and stagnant financial system, Islamic finance must innovate in a continually changing and growing world. This is a challenge for Islamic finance to stay relevant in the face of ever-increasing competition (Musari, 2019).

Otoritas Jasa Keuangan reacted with Sukuk Linked Waqf to the challenges of the Islamic Finance World. The main goal of this Sukuk issue is to strengthen sharia financial inclusion, which stayed at $6.7 \%$. This Sukuk offers the public a way of investing in the Islamic finance sector. The release of Sukuk is on the other hand a strategic step for the government to explore Indonesia's big potential waqf. Because commercialization dominates the global Islamic financial scene, inter-sector development between the financial and real economic sectors, as well as the social sector, is required within the Islamic economic system. Even though social sectors can genuinely deliver tremendous benefits to social welfare and justice, Waqf as a part of the social sector is rarely tapped for future development within the landscape (Musari, 2019).

Waqf intends to offer the community benefits as a social tool. This societal objective is part of the maqashid Sharia paradigm. Sukuk is however a financial platform to generate a profit. The two must consider sharia principles into consideration. Thus in the design of this product, the concept of maqashid sharia has been essential. The notion of performance measurement, known as maqashid sharia in Islamic economics, aims to give benefit (goodness) for humanity in this world and the afterlife. This notion incorporates both financial and social performance to increase benefits while reducing harm to the public good (Zuhaily, 1985).

Islam includes the freedom, as well as the development of Islamic financial products, to be creative and to innovate in the business. Maqashid sharia is among the concepts used. The concept of maqashid sharia is worldwide. Muslim scholars have pondered how to apply this principle in their context over time. The core of maqashid sharia is maslahah. Ibn As-Syur, a Maliki Mazhab Tunisian scholar, and Muhammad Abu Zahrah, who divided maqashid sharia into three dimensions and established maslahah as the ultimate objective of maqashid sharia, developed the notion. Financing activities for non-consumer (companies) with the concept of prosumer (businesses) with the concept of profit sharing will produce a larger benefit for the community if financial institutions make maqashid sharia their business goal (Antonio et al., 
2020). To comply with the maqashid sharia concept, the development of waqf through the issue of Sukuk Linked Waqf will be adjusted to the sharia principles. Sharia compliance in integrating Sukuk and waqf is a fundamental principle. The consequence is that Sukuk Linked Waqf's dualpurpose issuance will not conflict with the sharia principles. The efforts to revitalize Waqf through Sukuk are based on the aspect of the maslahah.

In addition, monetary waqf must be revitalized to reclaim its crucial role. Collaboration between Sukuk and cash waqf contracts is one option. Sukuk Linked Waqf can be viewed as a long-term funding tool that Islam is attempting to provide to help maintain the ratio of government spending that comes from, for, and by the people. Furthermore, Sukuk Linked Waqf has the potential to be a game-changing breakthrough for economic sustainability, particularly when it comes to supporting micro-communities without the use of interest rates (Fad, 2021).

With the issuance of the Sukuk Linked Waqf, Sharia investment products in the financial industry are increasingly diverse. This Sukuk is an option for long-term income people. The benefit achieved is that Waqf blesses itself, which always provides advantages. This makes it clear to the public that waqf can be developed for economic recovery and welfare. If the community is aware of the need for economic development and recovery, the government will feel the sustainable impact. The Islamic finance industry is the first choice of the community and will continue to grow to realize Islamic financial integration.

\section{METHOD}

This study employs a normative approach to library research. Popular books that were utilized to support the research and other works about the idea of maqashid sharia, such as Fiqh al-Islami wa Adillatuhu, Ushul Fiqh Abu Zahrah, and Sukuk, were the key sources of this research. The content analysis and critical analysis methods were employed in this study. This research aims to uncover the contents of a book as well as to comprehend, analyze, and present data explanations and interpretations (Syaichoni, 2020).

\section{RESULTS AND DISCUSSION}

\section{Sukuk Linked Waqf}

Bonds are one of the most well-known financial instruments. A bond is a statement letter debt issued by a bond issuer with the commitment to pay periodic compensation in the form of interest (coupon) and to repay the main debt at the set maturity. In the secondary market, bonds can be transferred or sold to other parties. Bonds are usually referred to as debt securities 
because of these qualities. Scholars prohibit the practice of issuing bonds because it comprises usury and violates Islamic law's sharia rules in the capital market. As a result, the Islamic financial system establishes a Sukuk instrument structure, which has characteristics similar to bonds but does not violate sharia rules in the capital market. Currently, the Sukuk concept has evolved to fulfill the demand of the financial industry. Some institutions' definitions also include the modern practice of issuing and trading Sukuk.

Sukuk can be defined in the terminology of the layman as a bond that conforms to Shariah (N. N. Fauziah et al., 2021). Sukuk or Islamic bonds are also termed muqarada bonds and are suggested as an alternative to bonds of interest. The Muqaradah is synonymous with the Mudaraba qiradh (Muhayatsyah, 2020). Sukuk is a certificate of equal value for undivided shares of tangible assets, usufructs, and services, or, as owners of, actives of certain projects or special investing activity, the accounting, and auditing organization of Islamic Financial Organizations (Accounting and Auditing Organization for Islamic Financial Institutions, 2015).

The Sukuk-waqf paradigm that has always been developed is Sukuk Linked Waqf. Sukuk's fundamental idea is to finance a producing waqf asset. The foundation of the Sukuk Linked Waqf is generally a waqf asset. The finances generated by Sukuk are utilized to create projects on waqf land by using waqf assets as a basis (Musari, 2019). Waqf is from Arabic, alwaqf that implies holding or stopping. Waqf is to withhold property to be used but not for itself, while the thing and its goods are employed for good and draw further to Allah (Rahayu \& Agustianto, 2020) and waqf is used to achieve the potential and economic advantages of waqf property to enhance the worship of the people (N. D. Fauziah \& Tulmafiroh, 2020).

Waqf's concerns have been important because of the efforts of modern scholars, who have shown the benefits of Waqf's activities in contemporary society, including its applications and the challenges involved. Most prior studies have shown that waqf cash is an efficient tool to be an alternative to reducing poverty because these projects need vast amounts that the government cannot get altogether (Yasin, 2021). Two forms of waqf and Sukuk combinations are being developed, namely Cash Waqf Linked Sukuk and Sukuk Linked Waqf. Both are today the new mixed financing for modern waqf instruments.

CWLS is a modern combined fiscal financing instrument in Indonesia (Musari, 2021). Otoritas Jasa Keuangan developed the Sukuk Linked Waqf concept to maximize the potential of waqf while strengthening the market share of Islamic commercial finance. By establishing infrastructure on waqf land, the goal is to expand the number of productive waqfs. It is intended that once the infrastructure is in place, Nazir's income would increase, allowing him to play a larger part in maukuf alaih empowerment. The implementation of Sukuk Linked Waqf is divided 
into two general schemes: nazir as a Sukuk issuer and another party as a Sukuk issuer. Sukuk waqf is a financial asset with the same legality and can be traded with a written document or certificate. This document discusses the contributed money. The main concept of all finances is either donated funds or fixed assets, such as money, planes, vehicles, cattle, and other movable assets or movable assets (Himam \& Umam, 2018).

Sukuk Linked Waqf is a new tool for the preservation and development of waqf assets and waqf funds. Therefore, Sukuk issuances may be considered in the field of waqf with many waqf assets or cash, either as funding or as an asset underlying the growth of waqf properties. Connecting waqf to Islamic finance as a social tool with Sukuk to Islamic finances as a commercial tool will draw market involvement for society development. However, the government has difficulty implementing this principle in the Indonesian issue. The basic reason for this is that the underlying waqf lands are not government property hence they contradict the regulations.

Similarly, the application of the concept also poses challenges with state-owned companies since Sukuk Linked Waqf may interrupt liquidity (Musari, 2019). In moreover, the Sukuk Linked Waqf notion is intended to address the Nazir who has no sources of financing for the building. To get finances, the Nazir could propose the appointment of a Special Vehicle (SPV) to an originator by the government and then Sukuk could collect revenue on the contract for a while. The originator could sign a contract with the developer to build the building on the property of waqf following the collection of the necessary funds. In this way, a tenant might be rented to create money to pay the tenant and return the building. The waqf asset may be passed back to the Nazir after maturity and the Nazir managed the construction and brought benefits to society (Musari, 2019). This waqf product has a very great economic potential to flourish since this money waqf model has a much more equal reach and mobility across the community than the old Waqf model (land and building waqf). Because only families or persons considering themselves wealthy or wealthy, the waqf provider reaches, and the production increases of waqf assets can be made in form of land and buildings (Paul et al., 2021).

Sukuk Linked Waqf provides the money required to purchase farms and build a sustainable awqaf sector. The Sukuk Linked Waqf engineering system to solve the gap between the profit-making and the non-profit sectors, maximize project use and exploitation of charitable resources, perhaps regulate national livestock meat production (Musari, 2019). Sukuk linked Waqf is an Islamic finance concept founded on the principles of morality and fairness, hence Sukuk Linked Waqf has to compliant Shari'ah Islamic principles on its operational basis from the 
instruments of the Qur'an, Hadith, and Ijma, namely fair, lawful, Tayib and Maslahat transactions (Paul \& Faudji, 2020).

\section{The Function of Sukuk Linked Waqf}

Sukuk Linked Waqf's functions include fiscal sustainability, the velocity of money, and sustainable development in the study of Islamic economics. Fiscal sustainability, firstly. In Islamic economics, the investment depends on the current rate of return on investments. As an investing function, Sukuk-waqf has a role. Sukuk-waqf will preserve economic stability as an investment instrument. The expansionary and investment expenses might be expressed by fiscal measures which foster the national economy.

Investment costs can then be a stimulus for domestic economic growth. Thus, the economic activities represent actual economic activity through the existence of the underlying assets in Sukuk-waqf. The effects of this condition will strengthen the government's primary surplus and establish fiscal sustainability over the long run (Musari, 2019). The second, money's velocity. Sukuk-waqf, who provides an investment function, can manage money supply and demand naturally, based on fiscal sustainability arguments. Sukuk waqf can therefore be a technique to restrict the supply of money through the monetary transfer mechanism. IMOs have a liquidity management mission to support real-world sector transactions. Sukuk Linked Waqf will support the deepening of the Islamic monetary market needed for managing cash flows in the real sector. Consequently, Sukuk-waqf contributes to propelling the treasures into the real sector, improving the velocity of money (Musari, 2019). Thirdly, development sustainability.

While Islamic finance doesn't need to be particularly stable and dependable against financial shocks. Islamic finance can give outstanding economic development ideas. Islamic finance has a major role in the development of social welfare, especially in enhancing social sustainability. Islamic finance can boost economic activity and entrepreneurship to alleviate poverty and ensure financial and social stability and promote integral human development and equity for all the sustainable development objectives of Islamic financing (SDGs) (Musari, 2019).

\section{Maqashid sharia aspects in the establishment of Sukuk Linked Waqf}

God's goal laws, Maqashid Sharia, are to enhance human civilization while avoiding various kinds of risks, both in this world and in the hereafter (Khatib, 2018). Based on maqashid sharia teachings, Islam introduces the benefit, safety, and welfare of nature (Hadi \& Baihaqi, 2020). The book of ushul fiqh by Abu Zahrah has an explanation of maqashid sharia. Abu Zahrah says that maqashid sharia has three parts in the chapter on maqashid al-ahkam (the goal of Islamic law). According to Abu Zahrah, maqashid sharia has three aspects: first, educating individuals (tahdzib al-fard), second, establishing fairness (iqamah al-'adl), and third, promoting 
public welfare (jalb al-maslahah) (Zahrah, 1958). This is in contrast to Imam al Syatibi's interpretation of maqashid sharia. Protecting religion, the soul, mind, property, and offspring are all examples of maqashid al-sharia, according to Imam Asy-Syatibi.

The maqashid al-sharia, according to Imam As-Syatibi, completes the tahsil and ibqa. Ibqa is concerned with preventing damage or injury, whereas tahsil is focused on securing rewards (Hadi \& Baihaqi, 2020). According to Abu Zahrah's viewpoint on Sukuk Linked Waqf items, aspects of maqashid sharia can be explained as follows. First and foremost, individuals must be educated (tahdzib al-fard). Is a type of attempt to develop and empower waqf assets in the context of the issue of Sukuk Linked Waqf. To promote the welfare of the people, waqf assets that are no longer productive are rejuvenated.

A waqf, according to Abu Zahrah, is a kind of worship to Allah. This commandment teaches individuals to obey Allah's commands and avoid his prohibitions to worship him. The objective of issuing Sukuk Linked Waqf is merely to carry out Allah's instructions by developing waqf, as stated in the context of the issue of Sukuk Linked Waqf. Waqf is a sharia economic mechanism that has the potential to grow in the future. Waqf has a social function to play in poverty alleviation. Waqf is distributed to those who are in need. Then it is everyone's responsibility to build waqf assets so that they can have a greater impact. Humans are taught to build waqf assets to be profitable through the issuing of Sukuk Linked Waqf.

Establishing fairness (iqamah al-'adl) is the second aspect. There is a value of justice (al'adl) in the issue of Sukuk Linked Waqf. The purpose of issuing Sukuk for social reasons, which strives to achieve blessings and economic benefits to expand sharia financial inclusion, is considered as justice in this situation. Sukuk and waqf, two independent interests, are combined into one product frame. Sukuk is a profit-oriented economic instrument, whereas waqf is a nonprofit social instrument. Social objectives centered on the hereafter must be balanced against economic goals centered on the present. According to Islam, all human activity must take into account both the world and the afterlife. Issuing Sukuk Linked Waqf is one approach for accomplishing both. Promoting public welfare is the third aspect (jalb al-maslahah). Sukuk Linked Waqf is a sharia financial product aimed at improving communal welfare. The public's perception of waqf has shifted to one in which it is used for economic interests.

The issuance of Sukuk Linked Waqf allows for the optimization of idle waqf assets. The community's economy will be strengthened as a result of this revitalization. The issue of Sukuk Linked Waqf is one type of waqf philanthropy. Waqf orientation is focused on the community's growth and empowerment to achieve prosperity. This motivates nazir to effectively handle his assets. This Sukuk product, on the other hand, shows the community that waqf can be tied to 
economic pursuits. This product can help achieve the purpose of Islamic economics, which is to establish justice and social welfare.

\section{CONCLUSION}

This study concludes that the issuing of Sukuk Linked Waqf involves three features of maqashid sharia in Abu Zahrah's opinion. first, educating individuals (tahdzib al-fard), second, establishing fairness (iqamah al-'adl), and third, promoting public welfare (jalb al-maslahah). Waqf is a sharia economic mechanism that has the potential to grow in the future. Waqf has a social function to play in poverty alleviation. Waqf is distributed to those who are in need. Then it is everyone's responsibility to build waqf assets so that they can have a greater impact. The purpose of issuing Sukuk for social reasons, which strives to achieve blessings and economic benefits to expand sharia financial inclusion, is considered as justice in this situation. Sukuk Linked Waqf is a sharia financial product aimed at improving communal welfare.

\section{REFERENCES}

Accounting and Auditing Organization for Islamic Financial Institutions. (2015). Shari'ah Standards for Islamic Financial Institutions. King Fahd National Library Cataloging in Publication Data.

Antonio, M. S., Laela, S. F., \& Jazil, T. (2020). Abu Zahrah's Maqasid Sharia Model As a Performance Measurement System. Jurnal Akuntansi Multiparadigma, 11(3), 519-541. https://doi.org/10.21776/ub.jamal.2020.11.3.30

Fad, M. F. (2021). Waqf Linked Sukuk dalam Perspektif Maqashid Syari'ah. Journal of Islamic Studies and Humanities, 6(1), 44-62.

Fasha, S. N. S., Mohamed, O. E. B. M., Isa, M. Y. B. M., \& Mohamed, Z. Bin. (2018). The Development of Waqf via Sukuk Financing: the Case of Khazanah "SRI Sukuk." International Journal of Business, Economics and Law, 15(5), 143-148.

Fauziah, N. D., \& Tulmafiroh, A. (2020). Analisis Waqf Linked Sukuk Untuk Memberdayakan Tanah Yang Tidak Produktif. Jurnal Al-Tsaman, 1(1), 70-81.

Fauziah, N. N., Rabiah, E., Engku, A., \& Bacha, A. M. (2021). an Analysis of Cash Waqf Linked Sukuk for Socially Impactful Sustainable Projects in. 10(1), 1-10. https://journals.iium.edu.my/iiibf-journal/index.php/iif/article/view/521/223

Hadi, N., \& Baihaqi, J. (2020). The motive of CSR Practices in Indonesia: Maqashid al-Sharia Review. 8(2), 327-352. 
Himam, N. S., \& Umam, K. (2018). Modelling Sukuk waqf For Pesantren Economic development. Journal of Islamic Economics and Philanthropy (JIEP), 1(3), 1-23.

Ilmiah, D. (2019). Optimalisasi Asset Wakaf Melalui Sukuk Wakaf di Indonesia. JESI (Jurnal $\begin{array}{llll}\text { Ekonomi } & \text { Syariah } & \text { Indonesia), } & \text { IX(2), }\end{array}$ http://ejournal.almaata.ac.id/index.php/JESI/article/view/1251

Khatib, S. (2018). Konsep Maqashid Al-Syari'ah: Perbandingan antara Pemikiran Al-Ghazali dan Al-Syathibi. MIZANI: Wacana Hukum, Ekonomi Dan Keagamaan, 5(1), 47-62.

Muhayatsyah, A. (2020). Aspek Syariah Pada Instrumen Sukuk: Analisis Penerapan Sukuk Wakaf Di Indonesia. J-ISCAN: Journal of Islamic Accounting Research, 2(2), 67-91. https://doi.org/10.52490/j-iscan.v2i2.891

Musari, K. (2019). The Evolution of Waqf and Sukuk toward Sukuk-Waqf in Modern Islamic Economy. International Journal of 'Umranic Studies , 2(1), 45-54.

Musari, K. (2021). Esham, the Origin of Sukuk for Facing the Crisis: Historical Experience. $\begin{array}{llll}\text { IQTISHODUNA: } & \text { Jurnal }\end{array}$ https://doi.org/10.36835/iqtishoduna.v10i1.945

Paul, W., \& Faudji, R. (2020). Cash Waqf Linked Sukuk Dalam Optimalkan Pengelolaan Wakaf Benda Bergerak (Uang). Jurnal Ilmiah MEA (Manajemen, Ekonomi, Dan Akuntansi), $4(2), 1-18$.

Paul, W., Faudji, R., \& Bisri, H. (2021). Cash Waqf Linked Sukuk Alternative Development of Sustainable Islamic Economic Development Sustainable Development Goals (SDG's). International Journal of Nusantara Islam, 9(1), 134-148. https://doi.org/10.15575/ijni.v9i1.12215

Rahayu, R. D., \& Agustianto, M. A. (2020). Analisis Implementasi Cash Waqf Linked Sukuk (CWLS) Perspektif Prinsip Ekonomi Syariah. Management of Zakat and Waqf Journal (MAZAWA), 1(2), 145-161. https://doi.org/10.15642/mzw.2020.1.2.145-161

Syaichoni, A. (2020). Ijarah Maushufah Fi Al-Dzimmah dalam Kajian Muamalah Kontemporer. Jurnal Syntax Transformation, 1(10), 668-675.

Yasin, R. M. (2021). Cash Waqf Linked Sukuk: Issues, Challenge and Future Direction in Indonesia. 7(1), 100-112. https://doi.org/10.20473/jebis.v7i1.24818

Zahrah, M. A. (1958). Ushul Fiqh. Dar al-Fikr.

Zuhaily, W. (1985). Al-Fiqh Al-Islamiy Wa Adillatuhu. Dar al-Fikr 